NBER WORKING PAPER SERIES

\title{
MEASURING THE ECONOMIC EFFECT OF GLOBAL WARMING ON VITICULTURE USING AUCTION, RETAIL, AND WHOLESALE PRICES
}

\author{
Orley C. Ashenfelter \\ Karl Storchmann \\ Working Paper 16037 \\ http://www.nber.org/papers/w16037
NATIONAL BUREAU OF ECONOMIC RESEARCH
1050 Massachusetts Avenue
Cambridge, MA 02138

May 2010

We are indebted to many people in the Mosel Valley for assistance with our research, but particularly to Rita and Clemens Busch of Pünderich. We are indebted to Kym Anderson, Victor Ginsburgh, Robert Stavins and especially Michael Greenstone and Victor Tremblay for helpful comments on an earlier draft of this paper. We thank Hubert Schnabel of Vereinigte Hospitien Trier for providing the wholesale price data. The views expressed herein are those of the authors and do not necessarily reflect the views of the National Bureau of Economic Research.

NBER working papers are circulated for discussion and comment purposes. They have not been peerreviewed or been subject to the review by the NBER Board of Directors that accompanies official NBER publications.

(C) 2010 by Orley C. Ashenfelter and Karl Storchmann. All rights reserved. Short sections of text, not to exceed two paragraphs, may be quoted without explicit permission provided that full credit, including (c) notice, is given to the source. 
Measuring the Economic Effect of Global Warming on Viticulture Using Auction, Retail, and Wholesale Prices

Orley C. Ashenfelter and Karl Storchmann

NBER Working Paper No. 16037

May 2010

JEL No. D44,L66,Q1,Q5,Q51

\begin{abstract}
In this paper we measure the effect of year to year changes in the weather on wine prices and winery revenue in the Mosel Valley in Germany in order to determine the effect that climate change is likely to have on the income of wine growers. A novel aspect of our analysis is that we compare the estimates based on auction, retail, and wholesale prices.

Although auction prices are based on actual transactions, they provide a thick market only for high quality, expensive wines and may overestimate climate's effect on farmer revenues. Wholesale prices, on the other hand, do provide broad coverage of all wines sold and probably come closest to representing the revenues of farmers. Overall, we estimate a $1^{\circ} \mathrm{C}$ increase in temperature would yield an increase in farmer revenue of about 30 percent.
\end{abstract}

Orley C. Ashenfelter

Center for Labor Economics

University of California

631B Evans Hall

Berkeley, CA 94720-3880

and NBER

c6789@princeton.edu

Karl Storchmann

Department of Economics

New York University

New York, NY 10012

storchkh@whitman.edu 


\section{Introduction}

In this paper we assess the economic impact of global warming on viticulture in the Mosel Valley of Germany. There are two features that are unique to the Mosel region. First, located between $49.61^{\circ}$ and $50.34^{0}$ latitude, all Mosel vineyards are situated near the far northern boundary for commercial grape growing. As a result, quality wine production in the Mosel Valley depends on special site characteristics and favorable weather conditions to ensure winter survival and ripening (Ashenfelter and Storchmann, 2010). Thus wine prices, crop yields, and wine quality are crucially dependent on weather and vary widely from year to year. Second, within the comparatively narrow Mosel Valley, most vineyards are planted on steep slopes of rocky, relatively unfertile soil (mostly slate) that is inappropriate for crops other than vines. Therefore, given the limited possibilities of crop substitution or alternative land usages, temperature-induced changes in viticulture directly reflect the economic impact of global warming in this part of Germany.

We use the so-called "Ricardian" approach applied by Mendelsohn, Nordhaus, and Shaw (1994) to the study of the effects of climate change on agriculture. Their empirical research, based as it is on hedonic models from highly aggregated data, has been critiqued and extended to consider difficult issues of functional form and specification by Schlenker, Hanemann, and Fisher (2005 and 2006), and Deschênes and Greenstone (2007). These more recent studies generally find considerable heterogeneity in the expected effects of climate change. Depending on the region considered, climate change may lead to either positive or negative effects on land values, with considerable uncertainty about the aggregate effect. Our approach follows this more recent work by studying a very specific area and type of crop and by establishing the economic relation using time-series variation in the weather.

Particularly, we provide and compare the results of three models based on different price data: retail, wholesale, and auction prices. The empirical results of our models are broadly similar and indicate that the vineyards of the Mosel Valley will increase in value under a scenario of global warming, and perhaps by a considerable 
amount. Vineyard and grape prices increase more than proportionally with greater ripeness; we estimate that a $3^{\circ} \mathrm{C}$ increase in temperature would more than double the value of this vineyard area, while a $1^{\circ} \mathrm{C}$ increase would increase vinyard prices by more than 25 percent.

\section{Data and Model}

This analysis is aimed at analyzing the effect of year to year fluctuations in the weather on prices and profits of viticulture in the Mosel Valley of Germany. Since overall per hectare cost is independent of changes in temperature and precipitation (Ashenfelter and Storchmann, 2010), our study focuses on revenue and its components. In general, we examine per hectare revenue from 1997 to 2008 in each of the five viticultural districts (called Bereich) of the Mosel valley, the Upper Mosel (from Luxemburg to the City of Trier), the Middle Mosel (from Trier to the village of Pünderich), the Lower Mosel (from Zell to the Rhine River), and the two Mosel tributaries: the Saar and the Ruwer Valley.

Although revenue is the simple product of price and crop yield, there is an added complexity in the study of the prices of German wines that results from the way that the wines are labeled and marketed. German wines are classified (and labeled) according to the natural sugar content of the unfermented grape must (freshly pressed grape juice), as measured on the Oechsle scale. ${ }^{1}$ In general, sweeter unfermented musts lead to higher alcohol volumes (and not necessarily sweeter wines), more aroma, and thus higher quality. In ascending order, the quality levels and Oechsle thresholds for Mosel wines are Quality Wine (lowest quality category, no ${ }^{\circ} \mathrm{Oe}$ requirement), Kabinett $\left(70^{\circ} \mathrm{Oe}\right)$, Spätlese $\left(76^{\circ} \mathrm{Oe}\right)$, Auslese $\left(83^{\circ} \mathrm{Oe}\right)$, Beerenauslese $(B A)\left(110^{\circ} \mathrm{Oe}\right)$, Eiswein $^{2}\left(110^{\circ} \mathrm{Oe}\right)$, and Trockenbeerenauslese $(T B A)\left(150^{\circ} \mathrm{Oe}\right)$. A primary quality distinction is that, with the

\footnotetext{
${ }^{1}$ Degrees Oechsle $\left({ }^{\circ} \mathrm{Oe}\right)$ is used in Germany and Switzerland and denotes the specific weight of the must compared to the weight of water at a temperature of $20^{\circ} \mathrm{C}$, while much of the English-speaking world uses a measure called brix. One liter of water weighs $1000 \mathrm{~g}$, which equals zero degrees Oechsle. Accordingly, grape must with a mass of 1084 grams per liter has $84^{\circ} \mathrm{Oe}$. Since the mass difference between equivalent volumes of must and water is almost entirely due to the dissolved sugar in the must, degrees Oechsle measures the relative sweetness of the grape juice. Approximately, one brix is equal to one degree Oechsle divided by 4.35 (Peynaud, 1984).

${ }^{2}$ The quality category Eiswein has the same Oechsle requirement as Beerenauslese (i.e., $110^{\circ} \mathrm{Oe}$ ). However, Eiswein grapes need to be harvested while frozen.
} 
exception of Quality Wine, it is illegal to add sugar to the must. As a result, wine prices are distinguished by the vineyard where the grapes are grown and by the quality level.

Although revenue per hectare data are not readily available, they can be computed by multiplying crop yield data by the average prices for each district and each wine quality level. Let $R_{i d t}, P_{i d t}$ and $Q_{i d t}$ denote per hectare revenue, price, and quantity produced of wine quality level $i$ in district $d$ and at time $t$; then

(1) $R_{i d t}=\sum_{i=1}^{7} \sum_{d=1}^{5}\left(P_{i d t} \cdot Q_{i d t}\right)$.

Total revenue in wine district $d$ will be determined by prices and quantities produced in each quality category.

Wine production data by district and quality category for the years 1997 to 2008 were prepared and provided by the Statistical Office of the State of Rheinland-Pfalz and its agricultural commission (Landwirtschaftskammer). ${ }^{3}$ Detailed production data for the time period before 1997 are not available.

Wine prices by quality category and viticultural district are not readily available but can be computed by drawing on various wine price data. We use three different sources -- retail, wholesale, and auction data -- and generate quality- and district-specific wine prices and revenue data.

Each data set has advantages and disadvantages. A disadvantage of the retail and wholesale price data is that they refer to posted prices, which may not be transaction prices. An advantage of these data is that they cover a wide range of Mosel wine producers. The auction prices refer to actual transaction prices, but only a tiny fraction of the very finest Mosel wines are sold at auction. As a result, the auction prices may not be representative of the region more generally.

Our retail price data come from the 1994-2008 issues of the Gault Millau Wine Guide for Germany (Diel and Payne, 1994-2008). The wine guide provides detailed information about the wines' characteristics such as age, geographical origin (vineyard and wine district), and quality classification, and the data permit us to calculate wine prices for each wine district and quality level accounting for other characteristics.

\footnotetext{
${ }^{3}$ These data are available, by request, from the authors.
} 
The wholesale price data come from the Mainz Wine Trade Fair (Mainzer Weinbörse). Once a year for two days, the fair showcases the wines of about 100 VDP estates. ${ }^{4}$ The fair is open to the wine trade only. Our dataset covers the fair years 1993 to 2001 and contains a total of 1063 wines from the Mosel wine region (Mainzer Weinbörse, 1993-2001).

Our auction price data come from the period 1981-2008 from the wine associations VDP Grosser Ring ${ }^{5}$ and Bernkasteler Ring (VDP Grosser Ring, 1992-2008; Bernkasteler Ring, 1981-2008). These groups of wineries have existed for more than 100 years and annually present and sell the latest vintage of their wines at the retail level. However, over the last 40 years, the character and role of their annual wine auctions has fundamentally changed. During the first decades after their establishment the two associations marketed the majority of their wines through auctions. Auctions were held twice a year; most wines were sold in 1000 liter barrels; and the wines that are offered comprised all categories of the quality spectrum with an emphasis on lower qualities.

Now, each association holds only one auction per year; all offered wines are bottled; and bulk wine (lower qualities sold in barrels) has not been put to auction since 1974. For instance, in 1954, the then 24 member wineries of the Bernkasteler Ring auctioned a total of 447,700 bottle-equivalents of wine. The majority of these wines were below the Spätlese quality level, and almost all were sold in bulk. In contrast, in 2008, the now 34 member wineries auctioned off a total of just 3,150 bottles, only 480 of which were below the Spätlese quality level. That is, while wine auctions in the Mosel Valley may have been representative of the regional wine production at large for most of the past century, they now instead serve as a vehicle for showcasing a few high-quality wines. Our auction sample focuses almost exclusively on the upper end of the quality scale; only $0.13 \%$ of all wines auctioned are Quality Wines (lowest quality category). In comparison, $74.1 \%$ of all wines produced are Quality Wines (see also Table 2).

Table 1 provides the descriptive statistics of the three price samples. It is apparent that the sample characteristics are largely different. While the average real wholesale

\footnotetext{
${ }^{4}$ In Germany, most high-quality wine producers are organized in the Association of German Quality Wine Estates (Verband Deutscher Prädikatsweingüter VDP). See also Schnabel and Storchmann (2010).

${ }^{5}$ Data for VDP Grosser Ring were available only from 1992 onward.
} 
price per 0.75 liter bottle equals $€ 6.19$ ( $\$ 8.04),{ }^{6}$ this is $€ 22.05$ (\$28.67) and $€ 77.32$ (\$100.52) for the retail and auction samples, respectively. These differences are even larger for the maximum prices. While the maximum wholesale price equals $€ 124.44$ (\$161.77), the most expensive wine at auction costs $€ 4211.11$ (\$5474.44). It is evident that the price differences are due to differences within each quality category as well as to the divergent structure of wines sold. Within each quality category, auction prices rank the highest, while wholesale prices are the lowest. In addition, while the wholesale sample does not comprise any Beerenauslese and Trockenbeerenauslese wines, these quality categories constitute a substantial part of all wine sold at auctions.

[Table 1 and Table 2 about here]

Table 2 reports the quality category shares of each price sample in comparison to the actual wine production from 1997 to 2008. It is apparent that the auction price sample is not likely to represent the Mosel wine production as a whole. While more than $12 \%$ of all wines sold at auction are of Eiswein, Beerenauslese, or Trockenbeerenauslese quality, this segment represents less than $0.2 \%$ of the overall production in the Mosel valley.

As we shall see, the response of prices to the average temperature during the growing season is very sensitive to the particular type of wine quality that is being studied, making it likely that these data may suffer from selection bias. In particular, since the prices of the higher quality wine types are much more responsive to temperature increases, the auction price data are likely to overstate dramatically the average effect of a temperature change on prices. Although we report the results using these data for completeness, we do not rely on them for our primary analysis.

Table 3 provides the descriptive statistics of the exogenous variables used for the three price models. For each sample, the difference between minimum and maximum growing season temperatures is well above 2 degree Celsius, a magnitude that equals the average expected warming for Europe for the next 90 years (Intergovernmental Panel on Climate Change, 2007).

\footnotetext{
${ }^{6}$ Assuming an exchange rate of $\$ 1.30 / €$.
} 
Wine production data by district and quality category for the years 1997 to 2008 were prepared and provided by the Statistical Office of the State of Rheinland-Pfalz and its agricultural commission (Landwirtschaftskammer). Table 3 reports the respective descriptive statistics. Since the production of high-quality wines stipulates a cap on yields per hectare the data already reflect farmers' adjustments to weather changes. Thus, in years with beneficial weather grape growers regularly remove some part of the crop in order to obtain higher quality fruit. "Yield reduction," as it is known, is common practice in the Saar, the Ruwer, the Middle Mosel and the Lower Mosel regions. Only in the Upper Mosel, where most wines are of lower quality and yield reduction is less common, do crop yields fully reflect weather variation.

[Table 3 about here]

\section{Results}

As originally shown by Ashenfelter and collaborators for the Bordeaux wine region, wine quality and price are highly depended on weather (Ashenfelter et al., 1995). In northern latitudes warmer and drier growing seasons are expected to lead to higher fruit quality. The precise relation varies with the grape type, but this relation has been quantified in many viticultural areas. ${ }^{7}$ Winter rainfall has also been shown to have a positive effect on fruit and wine quality, although this result has not been found for all of the viticultural areas where it has been studied. Our primary interest is in the effect of temperature on vineyard profits, but to the extent that rainfall and temperatures are correlated it is essential to control for these other aspects of the weather in the regressions. Therefore, the weather variables that we include in the regressions are (a) the average temperature over the growing season (Temp Growing Season), (b) the total rainfall in the growing season (Rain Growing Season), and (c) the total rainfall in the winter preceding the growing season (Rain Winter).

[Table 4 about here]

\footnotetext{
${ }^{7}$ See, for example, Ashenfelter and Storchmann (2010), Ashenfelter (2008), Haeger and Storchmann (2006), Jones and Storchmann (2001), Ashenfelter et al. (1995), and Ashenfelter and Byron (1995).
} 
Columns (1) and (2) of Table 4 contain the results of the price equation drawing on retail and wholesale prices, respectively. ${ }^{8}$ Since wines are labeled by their (1) quality level (in descending order of quality Trockenbeerenauslese (TBA), Beerenauslese (BA), Eiswein, Auslese, Spätlese, Kabinett, Quality Wine), and (2) their regions, we have interacted the temperature variable with each of these categories in order to produce quality- and region-specific temperature coefficient estimates. Quality Wine from the Upper Mosel serves as reference. It is apparent that warmer weather has a significantly positive effect on prices. Higher wine qualities, such as Trockenbeerenauslese, Beerenauslese and Eiswein benefit from a warmer growing season more than do lower qualities. In addition, the marginal effect of temperature increases is the highest in the districts of the Mosel tributaries Saar and Ruwer. The rainfall variables are either insignificant or have unexpected signs. The rainfall variables are either insignificant or have unexpected signs. This may reflect the fact that rainfall, in contrast to temperature, exhibits large local variations. While temperature changes at different locations in the Mosel Valley (and, in fact, in most of Europe; see Storchmann, 2005) are closely correlated, the precipitation data measured at a weather station some 50 miles away may be unrelated to the actual rainfall in the vineyard.

Aside from weather, a wine's quality is determined by its age. We included a variable age which denotes a wine's age when it was offered. Most age-worthy wines increase in value as they grow older, but most lower quality table wines do not. The overall effect, therefore, is unclear.

The results in column (3) indicate that auction prices are considerably more responsive to temperature changes than are retail and wholesale prices, as we expected. Interestingly, the age effect for the wholesale sample is negative, which may reflect the focus on lower quality wines that do not benefit from greater maturity.

[Table 5 about here]

\footnotetext{
${ }^{8}$ Note that the wholesale price sample does not contain prices for wines from the Lower Mosel district nor prices for Beerenauslese and Trockenbeerenauslese qualities.
} 
However, the use of these generated price data to compute revenue data, which will then again be regressed on weather data (see Table 6), might predetermine the weather-sensitivity of wine revenues. We thus generate district and quality-level specific price data by referring to the sugar content of the grape must (degree Oechsle) instead of weather. The results of these models are similar to the weather-related regressions and are reported in Table 5 .

To obtain an overall estimate of temperatures on gross revenue per hectare we must combine information on crop yields by region and quality level with the average prices by region and quality level.

Figure 1 shows the fraction of wines of Auslese and higher qualities as a part of the entire production in selected districts and the Mosel region as a whole over the period 1997-2008. The Ruwer region exhibits the highest variance with a range from $1 \%$ in 1998 to $52 \%$ in 2003 . Figure 1 also shows the average growing season temperature over the same period, and it is apparent that there is greater production of high quality wines in warmer years. The result is that (1) increases in temperatures result in increases in wine prices within each quality segment and (2) increases in temperatures also shift the quality structure of wines produced upward.

Another interesting feature of Figure 1 is the apparent upward trend in temperatures. ${ }^{9}$ At the same time there is also an apparent upward trend in the amount of higher quality wine being produced. This has led many observers to remark on the increased prosperity of the Mosel wine region in recent years. Figure 2 shows the annual growing season temperatures in the Mosel valley from 1960 to 2009. It is evident that the increase in average growing season temperatures began in the mid 1980s, well before our sample period. ${ }^{10}$ It is unclear, of course, whether this is a result of permanent climate change or something more transitory.

[Figure 1, Figure 2]

\footnotetext{
${ }^{9}$ Using data over the longer period from 1960 to 2006, a regression of average temperature on a trend variable (and a constant term) yields a coefficient of 0.034 at the $0.01 \%$ significance level. Thus, since 1960 average growing season temperatures in the Mosel valley have increased by 1.6 Centigrade.

${ }^{10}$ For longer time series data on weather and wine quality from the year 1700 onward see Storchmann (2005).
} 
Table 6 reports the relation between per hectare revenue and weather. In addition to weather variables we also included a trend variable to control for possible timedependent effects such as technological progress or changing marketability of Mosel wines as a whole. It is apparent that revenue per hectare significantly increases with warmer weather. However, the extent of this effect is dependent on the underlying price sample of the revenue data.

[Table 6 about here]

While the auction price-based sample suggests revenue increases of more than $63 \%$ per centigrade, the wholesale and retail price-based revenue date suggest revenue increases between $27 \%$ and $37 \%$ per centigrade. It is apparent that the auction pricebased sample measures the impact of temperature changes for high-end wine producers only. The focus of auctions on high-end wines suggests that the auction price-based sample is likely to overestimate the overall impact of temperature on revenue. In contrast, the other two samples, although based on very different price data, lead to similar results that are in a plausible range for the overall wine production in the Mosel valley. In addition, an entirely different model by Ashenfelter and Storchmann (2010), employing a model of solar radiation, also suggests revenue increases of about $30 \%$ per temperature increase by one centigrade. The rainfall variables are either insignificant or have unexpected signs. On the assumption that cost and temperature changes are not correlated (as shown by Ashenfelter and Storchmann, 2010), these revenue changes will translate directly into changes in profits and land values. Figure 3 displays the model results in graphical form.

[Figure 3 about here]

\section{Conclusion}

In this paper we have computed estimates of the effect of annual time-series weather changes on vineyard profitability and revenue. We provide and compare the results of three models that are based on different price data: retail, wholesale, and auction prices. All models suggest that the vineyards of the Mosel Valley will increase in value under a scenario of global warming, and perhaps by a considerable amount. We found that auction prices are likely to misrepresent the actual structure of Mosel wines 
produced, since auctions focus on the high end of the quality scale. They thus may overestimate the impact of temperature increases. In comparison, retail and wholesale prices lead to almost identical results that also are consistent with the results of Ashenfelter and Storchmann (2010), who use a hedonic model of solar radiation.

As is well known, there are likely to be winners and losers from any potential climate change. Wine revenue increases more than proportionally with greater ripeness, so that we estimate a $3^{\circ} \mathrm{C}$ increase in temperature would more than double the value of this vineyard area, while a moderate $1{ }^{\circ} \mathrm{C}$ increase would raise revenue by about 30 percent.

There are several limitations of these results: First, our empirical analysis does not take account of general equilibrium effects that might result in a restructuring of land prices. The Mosel Valley is suited primarily for grape growing only, so a change in the relative price of vineyards of different quality that would be induced by climate change could have a dramatic effect on our calculations. Second, our results provide only a small part of an overall appraisal of the role of climate change on agricultural values. There are no doubt places where increased temperatures will decrease the quality of wine grapes because of excessive heat. Only additional research will provide the evidence to evaluate these issues more completely.

\section{Acknowledgements}

We are indebted to many people in the Mosel Valley for assistance with our research, but particularly to Rita and Clemens Busch of Pünderich. We are indebted to Kym Anderson, Victor Ginsburgh, Robert Stavins, and especially Michael Greenstone for helpful comments on an earlier draft of this paper. We thank Hubert Schnabel of Vereinigte Hospitien Trier for providing the wholesale price data. We also thank the editor of this series, Victor Tremblay, and two anonymous referees whose comments helped to improve this paper substantially.

\section{References}


Ashenfelter, O. (2008). Predicting the Prices and Quality of Bordeaux Wines. The Economic Journal 118 (June), F174-F184.

Ashenfelter, O., Ashmore, D. \& Lalonde, R. (1995). Bordeaux Wine Vintage Quality and the Weather. Chance 8(4), 7-14.

Ashenfelter, O. \& Byron, R.P. (1995). Predicting the quality of an unborn grange. The Economic Record 71, No. 212, 40-53.

Ashenfelter, O. \& Storchmann, K. (2010). Using Hedonic Models of Solar Radiation and Weather to Assess the Economic Effect of Climate Change: The Case of Mosel Valley Vineyards. The Review of Economics and Statistics, 92(2), 333-349.

Bernkasteler Ring (1981-2008). Auktionsergebnisse. Annual Reports. Bernkasteler Ring, Bernkastel-Kues.

Deschênes, O. \& Greenstone, M. (2007). The Economic Impacts of Climate Change: Evidence from Agricultural Output and Random Fluctuations in Weather." American Economic Review, 97(1), 354-385.

Diel, A. \& Payne, J. (1994-2008). Weine Guide Deutschland. (Munich: Wilhelm Heyne.)

Haeger, J.W. \& Storchmann, K. (2006). Prices of American Pinot Noir Wines: Climate, Craftsmanship, Critics. Agricultural Economics, 35, 67-78.

Intergovernmental Panel on Climate Change (2007). Climate Change 2007: Synthesis Report. (Geneva, Switzerland: IPCC.) 
Jones, G. \& Storchmann, K. (2001). Wine Market Prices and Investment under Uncertainty: An Econometric Model for Bordeaux Crus Classés. Agricultural Economics $26,115-133$.

Mainzer Weinbörse (1993-2001). Mainzer Weinbörse: Die Fachmesse für Gastronomie und Fachhandel. (Mainz: Mainzer Weinbörse.)

Mendelsohn, R., Nordhaus, W.D. \& Shaw, D. (1994). The Impact of Global Warming on Agriculture: A Ricardian Analysis. American Economic Review, 84, 753-771.

Peynaud, E. (1984), Knowing and Making Wine. (New York: Wiley.)

Schlenker, W., Hanemann, W.M. \& Fisher, A. (2005). Will U.S. Agriculture Really Benefit from Global Warming? Accounting for Irrigation in the Hedonic Approach, American Economic Review, 95, 395-406.

Schlenker, W., Hanemann, W.M. \& Fisher, A. (2006). The Impact of Global Warming on U.S. Agriculture: An Econometric Analysis of Optimal Growing Conditions, Review of Economics and Statistics, 88, 113-125.

Schnabel, H. \& Storchmann, K. (2010). Prices as Quality Signals: Evidence from the Wine Market. Journal of Agricultural \& Food Industrial Organization, 8, Article 2.

Storchmann, K. (2005). English Weather and Rhine Wine Quality: An Ordered Probit Model. Journal of Wine Research, 16(2), 102-119.

VDP Grosser Ring (1992-2008). Auktionsergebnisse. Annual Reports. (Trier: VDP Grosser Ring.) 
Table 1

\section{Descriptive Statistics of Price Samples}

\begin{tabular}{|c|c|c|c|c|c|}
\hline & Mean & Minimum & Maximum & Std. Dev. & Observations \\
\hline & \multicolumn{5}{|c|}{ Retail } \\
\hline All & 22.05 & 2.21 & 543.81 & 40.58 & 6238 \\
\hline Quality Wine & 6.24 & 2.21 & 25.44 & 3.83 & 850 \\
\hline Kabinett & 5.96 & 2.83 & 20.73 & 1.92 & 1086 \\
\hline Spätlese & 9.26 & 3.80 & 71.70 & 5.45 & 2006 \\
\hline Auslese & 30.98 & 5.34 & 537.85 & 44.67 & 1785 \\
\hline Eiswein & 84.19 & 16.16 & 311.38 & 44.78 & 242 \\
\hline Beerenauslese & 90.41 & 24.35 & 543.81 & 65.45 & 187 \\
\hline \multirow[t]{2}{*}{ Trockenbeerenauslese } & 179.26 & 34.51 & 414.93 & 84.27 & 81 \\
\hline & \multicolumn{5}{|c|}{ Wholesale } \\
\hline All & 6.19 & 2.51 & 124.44 & 4.88 & 1063 \\
\hline Quality Wine & 3.95 & 2.51 & 9.71 & 0.78 & 259 \\
\hline Kabinett & 4.92 & 3.69 & 11.03 & 0.89 & 362 \\
\hline Spätlese & 6.84 & 4.51 & 19.34 & 1.73 & 328 \\
\hline Auslese & 12.51 & 7.08 & 40.10 & 5.53 & 112 \\
\hline Eiswein & 124.44 & 124.44 & 124.44 & & 1 \\
\hline Beerenauslese & & & & & 0 \\
\hline \multirow[t]{2}{*}{ Trockenbeerenauslese } & & & & & 0 \\
\hline & \multicolumn{5}{|c|}{ Auction } \\
\hline All & 77.32 & 2.97 & 4222.11 & 264.55 & 2398 \\
\hline Quality Wine & 8.15 & 7.92 & 8.35 & 0.22 & 3 \\
\hline Kabinett & 5.84 & 2.97 & 42.22 & 4.04 & 269 \\
\hline Spätlese & 12.16 & 3.88 & 343.60 & 16.52 & 759 \\
\hline Auslese & 45.04 & 5.31 & 1968.50 & 88.13 & 1074 \\
\hline Eiswein & 276.69 & 44.24 & 1427.17 & 267.06 & 96 \\
\hline Beerenauslese & 281.22 & 29.57 & 4222.11 & 441.67 & 129 \\
\hline Trockenbeerenauslese & 931.92 & 124.40 & 3939.96 & 968.88 & 68 \\
\hline
\end{tabular}

Prices in $€$ per 0.75 liter bottle. 
Table 2

Percentage Shares by Wine Quality Category

\begin{tabular}{lrrrrrrr}
\hline & $\begin{array}{l}\text { Quality } \\
\text { Wine }\end{array}$ & Kabinett & Spätlese & Auslese & Eiswein & $\begin{array}{c}\text { Beeren- } \\
\text { auslese }\end{array}$ & $\begin{array}{c}\text { Trocken- } \\
\text { beerenauslese }\end{array}$ \\
Retail & 13.63 & 17.41 & 32.16 & 28.61 & 3.88 & 3.00 & 1.30 \\
Wholesale & 24.37 & 34.05 & 30.86 & 10.54 & 0.09 & 0.00 & 0.00 \\
Auction & 0.13 & 11.22 & 31.65 & 44.79 & 4.00 & 5.38 & 2.84 \\
& & & & & & & \\
Production & 74.11 & 6.90 & 12.65 & 6.19 & 0.04 & 0.11 & 0.00 \\
\hline
\end{tabular}


Table 3

Descriptive Statistics of Exogenous Variables

\begin{tabular}{|c|c|c|c|c|}
\hline & Mean & Maximum & Minimum & Std. Dev \\
\hline & \multicolumn{4}{|c|}{ Retail } \\
\hline Temperature Growing Season (degree $C^{0}$ ) & 12.27 & 13.02 & 10.89 & 0.59 \\
\hline Rain Growing Season (mm) & 4735.92 & 6988 & 2777 & 1222.05 \\
\hline Rain Winter (mm) & 2000.17 & 3463 & 1198 & 682.85 \\
\hline \multirow[t]{2}{*}{ Age (years) } & 1.12 & 3 & 1 & 0.33 \\
\hline & \multicolumn{4}{|c|}{ Wholesale } \\
\hline Temperature Growing Season (degree $\mathrm{C}^{\mathrm{o}}$ ) & 12.18 & 12.79 & 10.89 & 0.57 \\
\hline Rain Growing Season (mm) & 4703.03 & 6988 & 2777 & 1108.96 \\
\hline Rain Winter (mm) & 2036.08 & 3463 & 1198 & 807 \\
\hline \multirow[t]{2}{*}{ Age (years) } & 1.17 & 8 & 1 & 0.58 \\
\hline & \multicolumn{4}{|c|}{ Auction } \\
\hline Temperature Growing Season (degree $C^{\circ}$ ) & 12.09 & 13.02 & 10.50 & 0.68 \\
\hline Rain Growing Season (mm) & 4530.09 & 6988 & 2353 & 948.98 \\
\hline Rain Winter (mm) & 1944.37 & 3463 & 616 & 591.76 \\
\hline \multirow[t]{2}{*}{ Age (years) } & 2.08 & 80 & 1 & 3.99 \\
\hline & \multicolumn{4}{|c|}{ Crop Yields 1997-2008 (hl/ha) } \\
\hline Mosel total & 101.4 & 122.2 & 80.8 & 11.89 \\
\hline Saar & 80.4 & 107.8 & 61.1 & 14.35 \\
\hline Ruwer & 67.6 & 90.7 & 50.6 & 11.88 \\
\hline Upper Mosel & 188.9 & 309.6 & 60.1 & 76.02 \\
\hline Middle Mosel & 107.9 & 130.8 & 83.6 & 12.84 \\
\hline Lower Mosel & 96.6 & 116.2 & 81.8 & 11.15 \\
\hline
\end{tabular}




\section{Table 4}

\section{Weather and Wine Prices}

\begin{tabular}{|c|c|c|c|}
\hline & $\begin{array}{c}(1) \\
\left.\ln (\text { Retail Prices })^{d}\right)\end{array}$ & $\begin{array}{c}\text { Dependent Variable } \\
(2) \\
\left.\ln (\text { Wholesale Prices })^{d}\right)\end{array}$ & ${ }^{(3)} \ln (\text { Auction Prices })^{d)}$ \\
\hline Constant & $\begin{array}{c}1.102 * * * \\
(7.29)\end{array}$ & $\begin{array}{c}1.347 * * * \\
(10.09)\end{array}$ & $\begin{array}{c}-1.926 \\
(-46.71)\end{array}$ \\
\hline Growing Season Temp ${ }^{\text {a) }}$ & $\begin{array}{c}0.042 * * * \\
(2.86)\end{array}$ & $\begin{array}{l}0.014 \\
(1.15)\end{array}$ & $\begin{array}{c}0.324 * * * \\
(2.95)\end{array}$ \\
\hline $\mathrm{TBA}^{\mathrm{e}) *}$ & $0.275 * *$ & & $0.327 * * *$ \\
\hline Growing Season Temp ${ }^{\text {a) }}$ & $(59.14)$ & & $(10.95)$ \\
\hline $\mathrm{BA}^{\mathrm{f}) *}$ & $0.217 * * *$ & & $0.238 * * *$ \\
\hline Growing Season Temp ${ }^{a)}$ & $(68.76)$ & & $(8.10)$ \\
\hline Eiswein* & $0.215 * * *$ & $0.284 * * *$ & $0.253 * * *$ \\
\hline Growing Season Temp ${ }^{\text {a) }}$ & $(73.14)$ & $(18.14)$ & $(8.76)$ \\
\hline Auslese* & $0.110 * * *$ & $0.092 * * *$ & $0.075 * * *$ \\
\hline Growing Season Temp ${ }^{a)}$ & $(55.28)$ & $(51.67)$ & $(2.59)$ \\
\hline Spätlese* & $0.037 * * *$ & $0.046 * * *$ & 0.002 \\
\hline Growing Season Temp ${ }^{\text {a) }}$ & $(24.35)$ & $(34.93)$ & $(0.03)$ \\
\hline Kabinett* & $0.004 * * *$ & $0.020 * * *$ & -0.041 \\
\hline Growing Season Temp ${ }^{\text {a) }}$ & $(2.59)$ & $(15.59)$ & $(-1.44)$ \\
\hline Middle Mosel* & 0.003 & $-0.006^{*}$ & 0.010 \\
\hline Growing Season Temp ${ }^{\text {a) }}$ & $(0.68)$ & $(-1.97)$ & $(0.41)$ \\
\hline Lower Mosel* & $0.009 * *$ & & 0.048 \\
\hline Growing Season Temp ${ }^{\text {a) }}$ & $(2.21)$ & & $(1.85)$ \\
\hline Saar* & $0.019 * * *$ & $-0.013 * * *$ & 0.036 \\
\hline Growing Season Temp ${ }^{a)}$ & $(4.81)$ & $(-4.09)$ & $(1.41)$ \\
\hline Ruwer* & $0.010 * * *$ & $0.004 *$ & 0.029 \\
\hline Growing Season Temp ${ }^{a)}$ & $(2.69)$ & $(0.14)$ & $(1.13)$ \\
\hline Rain Winter ${ }^{b)}$ & $\begin{array}{c}-0.001 * * * \\
(-4.95)\end{array}$ & $\begin{array}{c}0.014 * * * \\
(3.59)\end{array}$ & $\begin{array}{c}-0.002 * * * \\
(-4.45)\end{array}$ \\
\hline Rain Growing Season ${ }^{c}$ & $\begin{array}{l}0.0002 * * * \\
(2.57)\end{array}$ & $\begin{array}{c}-0.0002 \\
(-0.45)\end{array}$ & $\begin{array}{c}0.001 * * * \\
(5.26)\end{array}$ \\
\hline $\ln ($ age $)$ & $\begin{array}{c}0.341 * * * \\
(9.83)\end{array}$ & $\begin{array}{c}-0.0002 * * * \\
(-3.50)\end{array}$ & $\begin{array}{l}-0.094 \\
(-1.87)\end{array}$ \\
\hline R2 & 0.705 & 0.776 & 0.673 \\
\hline F statistic & $1060.92 * * *$ & $331.80^{* * *}$ & $350.80 * * *$ \\
\hline $\mathrm{n}$ & 6355 & 1063 & 2398 \\
\hline
\end{tabular}

a) February to October, b) December to February, c) April to October d) in real prices., e) Trockenbeerenauslese, f) Beerenauslese; significance levels of $1 \%(* * *), 2 \%(* *), 5 \%(*)$; Newey-West robust t-values in parentheses; 
Table 5

\section{Degree Oechsle and Wine Prices}

\begin{tabular}{|c|c|c|c|}
\hline & $\begin{array}{c}(1) \\
\ln (\text { Retail Prices }) \\
\end{array}$ & $\begin{array}{c}\text { Dependent Variable } \\
(2) \\
\left.\ln (\text { Wholesale Prices })^{d}\right)\end{array}$ & $\begin{array}{c}(3) \\
\ln (\text { Auction Prices }) \\
\text { d) }\end{array}$ \\
\hline Constant & $\begin{array}{l}0.267 \\
(1.58)\end{array}$ & $\begin{array}{c}1.328 * * * \\
(8.07)\end{array}$ & $\begin{array}{c}-2.762 * * * \\
(-8.24)\end{array}$ \\
\hline Degree Oechsle (Sugar & $0.017 * * *$ & 0.002 & $0.064 * * *$ \\
\hline Content of Grape Juice) & $(7.82)$ & $(0.81)$ & $(15.24)$ \\
\hline $\mathrm{TBA}^{\mathrm{e})}$ & $\begin{array}{c}3.355 * * * \\
(59.55)\end{array}$ & & $\begin{array}{c}4.407 * * * \\
(12.18)\end{array}$ \\
\hline$B A^{f)}$ & $\begin{array}{c}2.643 * * * \\
(66.41)\end{array}$ & & $\begin{array}{c}3.130^{* * *} \\
(8.70)\end{array}$ \\
\hline Eiswein & $\begin{array}{c}2.623 * * * \\
(75.41)\end{array}$ & $\begin{array}{c}3.452 * * * \\
(18.12)\end{array}$ & $\begin{array}{l}3.420 * * * \\
(9.69)\end{array}$ \\
\hline Auslese & $\begin{array}{c}1.336 * * * \\
(55.55)\end{array}$ & $\begin{array}{c}1.130 * * * \\
(51.21)\end{array}$ & $\begin{array}{c}1.079 * * * \\
(3.06)\end{array}$ \\
\hline Spätlese & $\begin{array}{l}0.440 * * * \\
(24.02)\end{array}$ & $\begin{array}{c}0.558 * * * \\
(34.54)\end{array}$ & $\begin{array}{l}0.223 \\
(0.63)\end{array}$ \\
\hline Kabinett & $\begin{array}{c}0.043 * * * \\
(2.34)\end{array}$ & $\begin{array}{c}0.240 * * * \\
(15.43)\end{array}$ & $\begin{array}{l}-0.194 \\
(-0.55)\end{array}$ \\
\hline Middle Mosel & $\begin{array}{l}0.039 \\
(0.05)\end{array}$ & $\begin{array}{c}-0.082 * * \\
(-2.08)\end{array}$ & $\begin{array}{l}-0.075 \\
(-0.22)\end{array}$ \\
\hline Lower Mosel & $\begin{array}{c}0.013 * * * \\
(2.54)\end{array}$ & & $\begin{array}{l}0.464 \\
(1.33)\end{array}$ \\
\hline Saar & $\begin{array}{c}0.241 * * * \\
(5.01)\end{array}$ & $\begin{array}{c}-0.168 * * * \\
(-4.23)\end{array}$ & $\begin{array}{l}0.266 \\
(0.79)\end{array}$ \\
\hline Ruwer & $\begin{array}{c}0.123 * * * \\
(2.67)\end{array}$ & $\begin{array}{c}0.162 * * * \\
(3.41)\end{array}$ & $\begin{array}{l}0.152 \\
(0.45)\end{array}$ \\
\hline $\ln ($ age $)$ & $\begin{array}{c}0.324 * * * \\
(9.65)\end{array}$ & $\begin{array}{c}-0.110 * * * \\
(-5.38)\end{array}$ & $\begin{array}{l}-0.289 \\
(-6.54)\end{array}$ \\
\hline R2 & 0.705 & 0.774 & 0.679 \\
\hline F statistic & $1240.79^{* * *}$ & $399.80 * * *$ & $\begin{array}{c}420 / 72^{* * *} \\
2305^{\mathrm{g})}\end{array}$ \\
\hline
\end{tabular}

a) February to October, b) December to February, c) April to October d) in real prices. e) Trockenbeerenauslese, f) Beerenauslese g) for three wines in the sample we could not obtain Oechsle measures; we thus only refer to 2395 of the 2398 wines; significance levels of $1 \%(* * *), 2 \%(* *), 5 \%(*)$; Newey-West robust $t$-values in parentheses; 
Table 6

\section{Weather and Revenue}

\begin{tabular}{|c|c|c|c|}
\hline & $\begin{array}{c}(1) \\
\ln (\text { Revenue based on } \\
\text { Retail Prices })^{d)}\end{array}$ & $\begin{array}{l}\text { Dependent Variable } \\
(2) \\
\ln (\text { Revenue based on } \\
\text { Wholesale Prices })^{d}\end{array}$ & $\begin{array}{c}\text { (3) } \\
\ln (\text { Revenue based on } \\
\text { Auction Prices })^{d}\end{array}$ \\
\hline Constant & $\begin{array}{l}8.251 \\
(0.34)\end{array}$ & $\begin{array}{l}18.166 \\
(0.89)\end{array}$ & $\begin{array}{c}-23.015 \\
(-0.66)\end{array}$ \\
\hline Growing Season Temp ${ }^{a)}$ & $\begin{array}{c}0.373 * * * \\
(2.82)\end{array}$ & $\begin{array}{c}0.265^{* *} \\
(2.47)\end{array}$ & $\begin{array}{c}0.633 * * * \\
(2.94)\end{array}$ \\
\hline Rain Winter ${ }^{\text {b) }}$ & $\begin{array}{l}-0.000 \\
(-0.07)\end{array}$ & $\begin{array}{l}-0.000 \\
(-0.28)\end{array}$ & $\begin{array}{l}-0.000 \\
(-0.19)\end{array}$ \\
\hline Rain Growing Season ${ }^{c}$ & $\begin{array}{c}-0.0002 * * * \\
(-3.40)\end{array}$ & $\begin{array}{c}-0.0001 * * * \\
(-2.91)\end{array}$ & $\begin{array}{c}-0.0002 * * * \\
(-2.87)\end{array}$ \\
\hline Trend & $\begin{array}{l}-0.003 \\
(-0.23)\end{array}$ & $\begin{array}{l}-0.007 \\
(-0.76)\end{array}$ & $\begin{array}{l}0.012 \\
(0.69)\end{array}$ \\
\hline $\begin{array}{l}\text { R2 } \\
\text { F statistic } \\
\text { n }\end{array}$ & $\begin{array}{c}0.767 \\
9.62 * * * \\
60\end{array}$ & $\begin{array}{c}0.793 \\
10.04 * * * \\
48\end{array}$ & $\begin{array}{c}0.785 \\
7.91 * * * \\
60\end{array}$ \\
\hline
\end{tabular}

a) February to October, b) December to February, c) April to October d) in real prices (district fixed effects are not reported). significance level of $2 \%(* * *), 5 \%(* *), 10 \%(*)$; t-values based on year-clustered standard errors in parentheses 
Figure 1

Growing Season Temperatures and High End Wine Production

Percentage production of Auslese+ Wines in Selected Mosel Districts

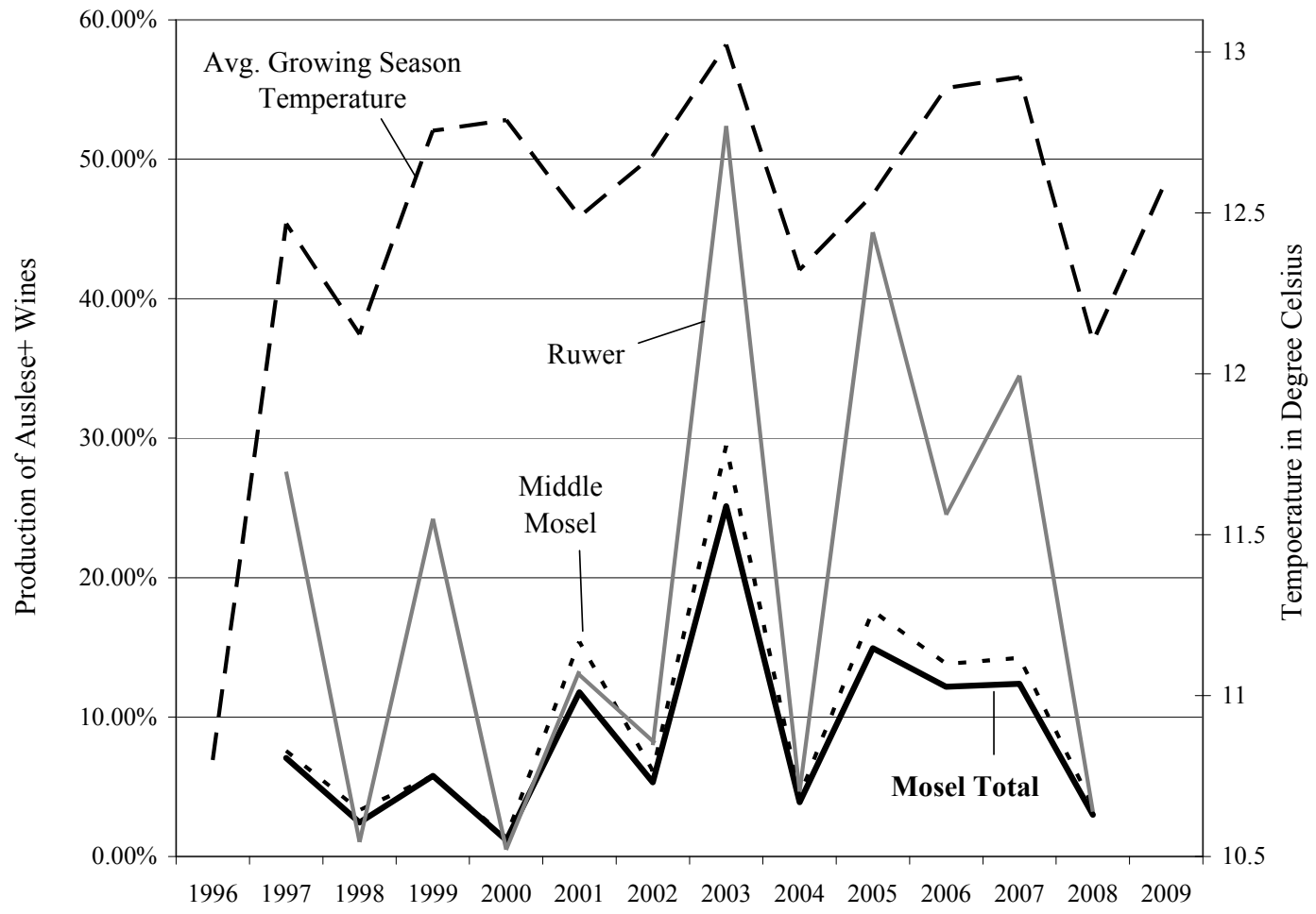


Figure 2

Average Growing Season Temperatures in the Mosel Valley 1960 - 2009 in degree centigrade

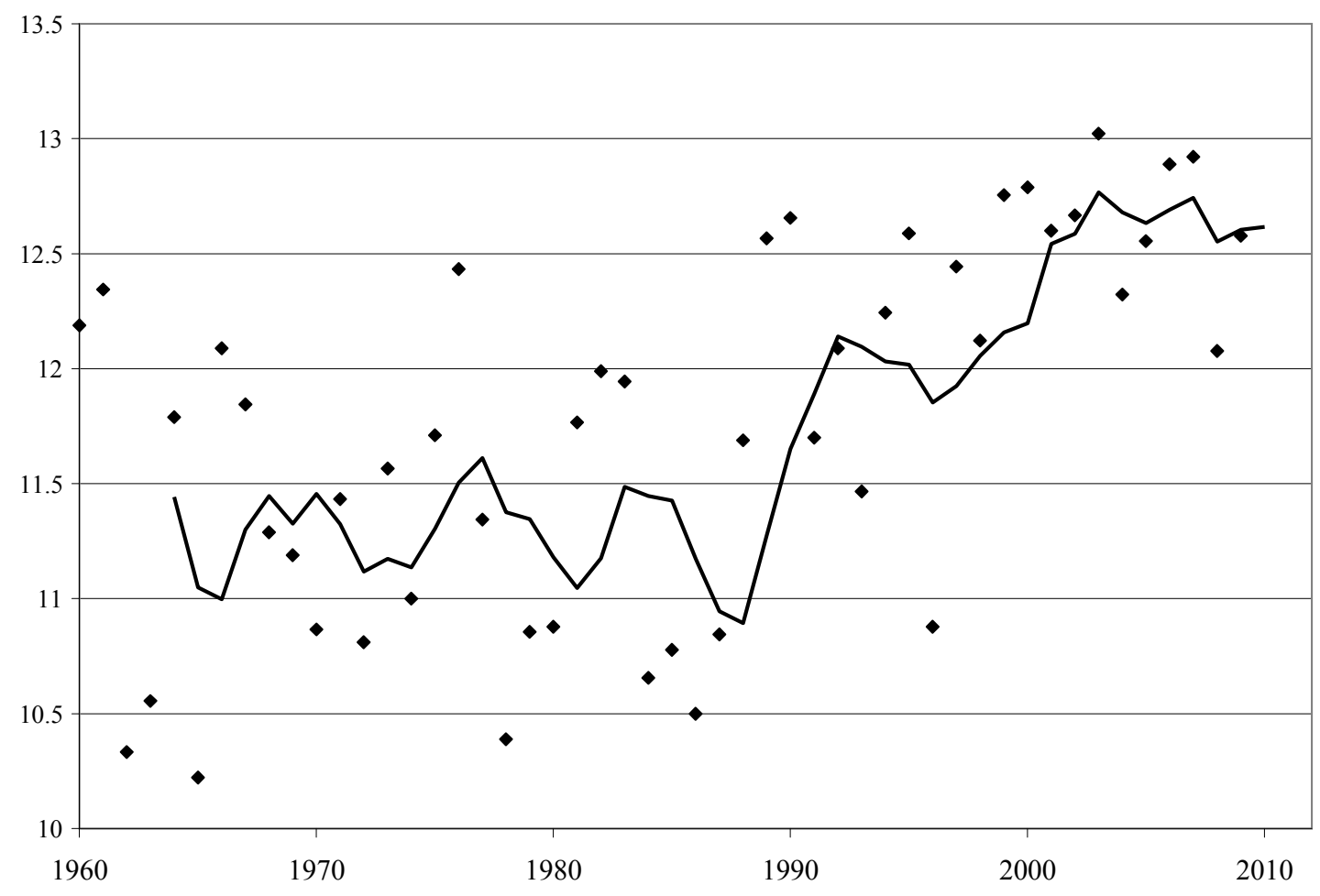

Note: solid line is a five-year moving average 
Figure 3

Temperature Changes and Percentage Changes in Revenue

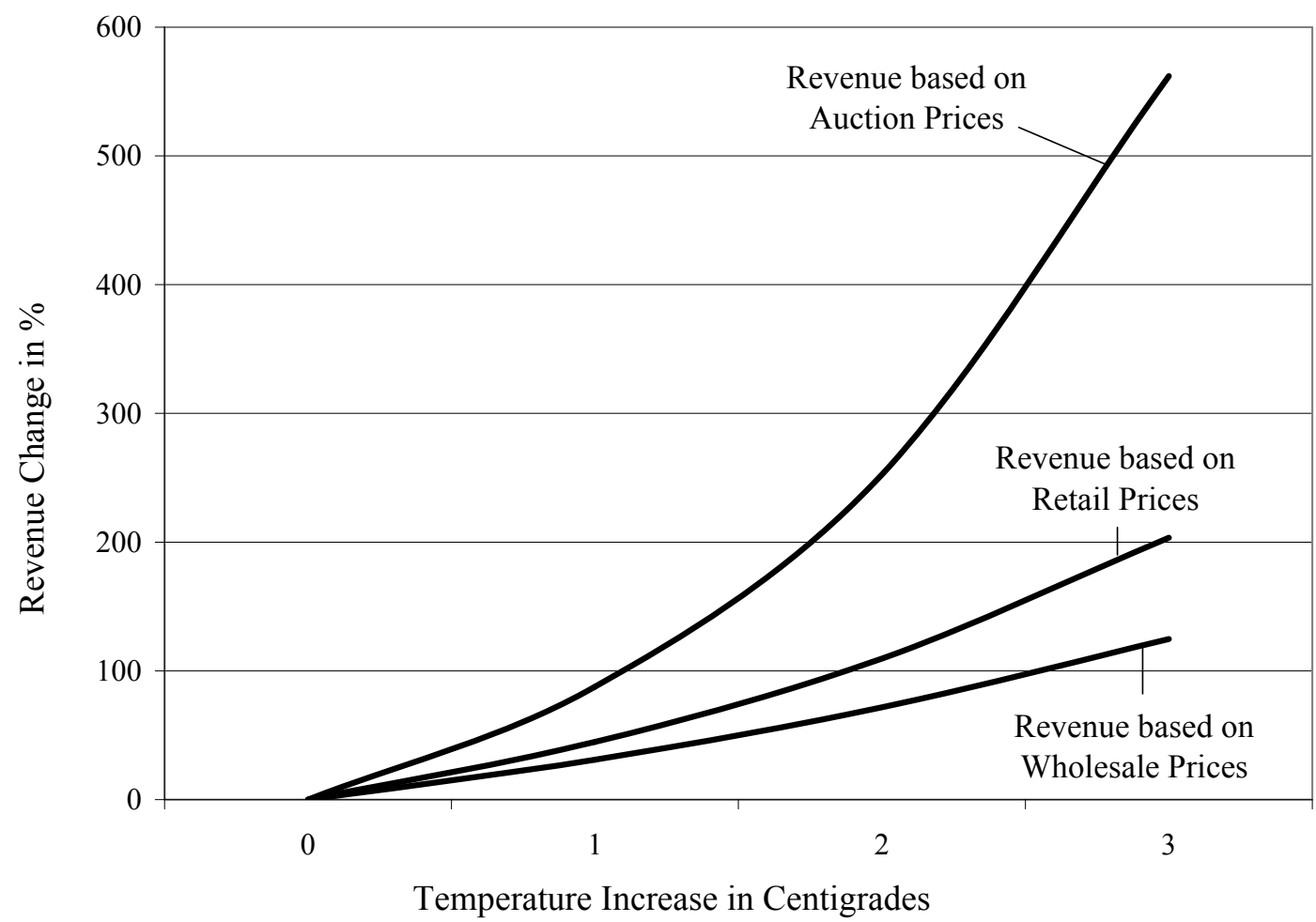

